\title{
Self-authorship, well-being and paternalism
}

\author{
Konstantinos Kalliris*
}

\begin{abstract}
Paternalism is the restriction of a person's autonomy for the good of that person. It embodies a familiar conflict of intuitions: while we cherish individual freedom, we also want to protect/promote what we know to be good. So, every paternalist must meet two challenges: paternalism must be justifiable as a restriction of autonomy as well as effective in terms of well-being. In this essay, I argue that the 'autonomy' restricted by paternalism is a Razian brand of free self-authorship and that the 'good' protected is captured by Martha Nussbaum's account of personal wellbeing. I then defend a mild welfare paternalism based on a dichotomy implicit in any defensible description of well-being. I argue that some aspects of the good life do not require endorsement and, therefore, can be justifiably and effectively promoted by autonomy-restricting means. Finally, I discuss why paternalism need not be hostile to ethical independence.
\end{abstract}

Keywords: paternalism; autonomy; self-authorship; well-being

This is a pre-print of an article submitted to Jurisprudence: An International Journal of Legal and Political Thought. The full text can be found here: http://dx.doi.org/10.1080/20403313.2015.1116200

\section{Introduction}

A large part of the still raging debate on paternalism focuses on freedom: paternalism, its opponents argue, infringes on individual freedom. 'This may be true', their dialogical adversaries reply, 'but it does so for a good reason, namely the good of the person whose freedom is restricted'. In this sense, paternalism embodies an interesting dimension of what can be described as a very old conflict of intuitions: on the one hand, we cherish freedom as something unquestionably valuable; on the other, we see the obvious value of leading a good life and most of us tend to think that, at least to an extent, this is an objective notion. When the presumption in favour of freedom prevails, as it often happens in the liberal camp, paternalism is a prima facie wrong: in principle, the individual's own good is not a good reason 
for the restriction of her freedom. ${ }^{1}$ Unless directed at children or those who cannot take care of themselves, ${ }^{2}$ paternalism is, in this view, presumptively blamable. ${ }^{3}$

In this article, I intend to propose a different approach: while I do not deny that a conflict much like the one just described is inherent to paternalism, I find the common liberal view that paternalism is, at best, a 'necessary evil'4 wanting. A closer look at the conflict itself will reveal that we can only resolve the puzzle that is paternalism by considering two pressing issues. Firstly, we must carefully determine what is wrong with paternalism. I will argue that the intuitive disapproval of paternalism most of us share is due to the fact that it infringes on a very particular kind of freedom: autonomy as self-authorship (sections 2 and 3). If I am right, we must concede (and this would remain a liberal ${ }^{5}$ view) that paternalism may, in principle, be justifiable despite its autonomy-restricting nature because autonomy ${ }^{6}$ is not an all-ornothing concept and it may make sense to restrict some (or some aspect of it) for the sake of

\footnotetext{
*For their valuable comments on various drafts of this article I would like to thank Sylvie Delacroix, Pavlos Eleftheriadis, John Gardner, Antonios Karampatzos, Grant Lamond, Harry Papadopoulos and Tobias Tröger, as well as the editors and two anonymous reviewers for this journal.

1 J. S. Mill, On Liberty and Other Essays, (Digireads.com Publishing, 2010), 10.

2 This is what most theorists describe as 'soft' paternalism.

3 Joel Feinberg, The Moral Limits of the Criminal Law Volume 3: Harm to Self, (New York: Oxford University Press, 1989), $4 \mathrm{f}$.

${ }^{4}$ Isaiah Berlin, introduction to Five Essays on Liberty, ed. Henry Hardy (Oxford: Oxford University Press, 2002), 53.

${ }^{5}$ By placing personal autonomy at the core of what I understand to be the main concern of the liberal tradition I follow in the footsteps of what Joseph Raz (The Morality of Freedom, (Oxford: Oxford University Press, 1986), 203) describes as a 'a common strand in liberal thought'. In one way or another, self-authorship is of paramount importance even for liberal or libertarian theorists who disagree with the account of freedom I am about to defend (see for example John Rawls, A Theory of Justice, (Cambridge, Mass: Harvard University Press, 1971), 923 and 408 or Robert Nozick, Anarchy, State and Utopia, (Oxford: Blackwell, 1974), 49-50). On the contrary, I move away from those who think that liberalism is a political principle that seeks to address the (freedomrelated) problems posed by the cultural and moral diversity inherent in (modern) societies. Autonomy is not a 'regulator' of antagonistic social ideals or ways of life but a distinct value worthy of protection and promotion. This allows for the possibility that life-styles and communities with little or no room for autonomy may enjoy less state protection, subsidy and even toleration than autonomy-respecting ones. For a diversity-based approach see William Galston, 'Two concepts of liberalism', (1995), Vol. 105, (3) Ethics, 516-534 and, in a more radical tone, Chandran Kukathas, The Liberal Archipelago: A Theory of Diversity and Freedom, (Oxford: Oxford University Press, 2003).

${ }^{6}$ By autonomy I will always mean personal autonomy as self-authorship. I do not mean to discuss the Kantian brand of moral autonomy as the ability to impose moral laws on ourselves.
} 
another value or even autonomy itself. Secondly, we need to take the paternalist's response ('I am interfering with another person's autonomy for her own good and this is always a prima facie good reason') more seriously. I will defend the position that there is an aspect of what is good for people that can benefit from paternalism and, more interestingly, state paternalism as we commonly understand it. More specifically, I will discuss an aspect of personal well-being, namely a group of goods or capabilities we commonly understand as basic or all-purpose. These goods/capabilities can be effectively protected by paternalism in general and legal paternalism in particular (section 4). By addressing these issues, I intend to respond to what I understand to be the two main arguments against paternalism: the argument from autonomy and the argument from efficiency (or the 'utilitarian' argument). I will then present a general principle regarding the balancing of autonomy on the one hand and the protection of these goods on the other, based on their significance both for wellbeing and for autonomy itself (section 4.2). This principle, I contend, is clear enough to serve as a rule of thumb for legislators and policy makers. Before concluding my argument (section 4.4), I will attempt to meet two anti-paternalistic challenges closely related to a crucial aspect of autonomy which I will, a little later in this work (section 2.3), describe as ethical autonomy.

So, in this article I will grapple with the most notorious problems still plaguing the debate on paternalism. As expected, they both concern the two main sides of the conflict described above: freedom and well-being. Let me briefly explain what I expect to accomplish by taking this path. Firstly, I will attempt to show why paternalism restricts personal autonomy as self-authorship as well as how this restriction takes place in the public domain. Interestingly, the issue is heavily contested in the literature. Theorists have relied on almost every known reading of the concept of freedom in order to describe what is wrong with 
paternalism, including liberty of action, ${ }^{7}$ respect for one's present will or prior commitment, ${ }^{8}$ the non-restriction of options ${ }^{9}$ and autonomy as the absence of coercion and manipulation. ${ }^{10}$ I will argue that a proper understanding of self-authorship and its value is the appropriate solution to this puzzle. This understanding will reveal that paternalism in general and legal paternalism in particular is not restricted to the familiar coercive threat expressed in seatbelt laws. Secondly, I will discuss what kind of good the paternalist ought to have in mind when she proclaims that 'it is for your own good'! Most discussions of paternalism seem to imply and some even implicitly discuss- the conflict between autonomy and well-being that runs through the concept of paternalism. However, there are only scarce references to the concept of well-being per se. This is a striking omission that is partly responsible for the scepticism many people share when asked to endorse a general pro-paternalism rule, even when they are convinced about the need for some paternalism (e.g. for seatbelt laws or mandatory pension schemes). At the very least, they fear the effects of a slippery slope: without a clear image of what kind of 'good' paternalism does, how can we know where it ends? I will attempt to show that a closer look at the concept of well-being reveals that these fears are unfounded. When this work is complete, the conflict of intuitions will be easier to resolve.

Before we can expand on these ideas, however, we need a provisional definition of paternalism. So, here it is: paternalism is the restriction of an individual's personal autonomy for the good of that individual. This definition already narrows down the concept in two important ways that I consider relatively uncontroversial: paternalism is not directed towards

\footnotetext{
${ }^{7}$ Gerald Dworkin, 'Paternalism' in eds. P. Laslett and J. Fishkin, Philosophy, politics and society, (Oxford: Blackwell, 1979), 78.

${ }^{8}$ Richard Arneson, 'Mill versus Paternalism', (1980), Vol. 90 (4), Ethics, 471.

9 John Kleinig, Paternalism, (New Jersey: Rowman and Allanhead, 1983), 19. Kleinig finds this approach promising but problematic.

${ }^{10}$ Gerald Dworkin, 'Paternalism: Some Second Thoughts', in ed. Rolf Sartorius, Paternalism, (Minneapolis: University of Minnesota Press, 1983), 107.
} 
children and those who lack the mental faculties to decide for themselves; paternalism is always autonomy-restricting. In other words, I will defend a concept that is neither 'soft' nor 'libertarian' paternalism ${ }^{11}$ - both of them present opportunities for a discussion that must remain separate.

\section{Autonomy as self-authorship}

\subsection{Self-authorship}

\subsubsection{Freedom}

The claim that paternalism has a bad name because it restricts autonomy as self-authorship neither presupposes nor entails that autonomy is the only brand of freedom that has value or makes sense. It is merely a restatement of the familiar idea that paternalism obstructs selfdetermination. In a paternalistic society, one is far less likely to be 'one's own master'. ${ }^{12}$ Crucially, self-authorship transcends the traditional dichotomy between positive and negative liberty, because it understands self-determination to require both. 'The ideal of personal autonomy is the vision of people controlling, to some degree, their own destiny, fashioning it through successive decisions throughout their lives' ${ }^{13}$ This kind of control cannot be achieved unless one enjoys both 'freedom from' and 'freedom to'. Freedom from external interference is fundamental because it gives us the 'breathing space' we need in order to lead the kind of life we prefer. Positive freedom, on the other hand, is about options or opportunities: ${ }^{14}$ people must have an adequate number of options from which to choose. Their options need to be

\footnotetext{
${ }^{11}$ For a brief discussion of libertarian paternalism, see pp. 26 and 39-40.

${ }^{12}$ As Berlin himself put it in 'Two concepts of liberty': Political Philosophy, ed. by A. Quinton, (Oxford: Oxford University Press, 1967) 149.

${ }^{13}$ Raz, (n 5), 369.

${ }^{14}$ I will use the term interchangeably.
} 
attainable and diverse in order to be considered as real opportunities for self-authorship. Without opportunities, we face the danger of settling, in the words of Hobhouse, for nominal instead of real freedom. ${ }^{15}$

These remarks are expected to trigger one of the most familiar liberal alarms: if people need positive liberty to be truly free, is this not a back door for the introduction of perfectionism or even elitism? Depending on how rigid one's account is, the state may be justified to even coerce people to 'be free', that is to live their lives as expected from those who are not merely 'free from' but also 'free to'. This fear is exaggerated because no good government can overlook the fundamental liberal value of value-pluralism: not one but many different and conceivably incompatible ways of life are valuable and worthy of protection. ${ }^{16}$ However, self-authorship does have a perfectionist aspect. Crudely put, it will not tolerate the non-practice of autonomy. People who drift through life, who spend their days without purpose, do not exercise self-authorship. In an autonomy-promoting environment, these people will no doubt feel much less comfortable than their autonomous peers. In this sense, autonomy is both an ideal and an exercise concept. It is far beyond the scope of this work to provide a complete account of autonomy as self-authorship. A rough description, however, is necessary and will be the subject of the following sections. My analysis will draw on Raz's account of personal autonomy, from which I will crucially depart before the end of this section.

\subsubsection{The concept of self-authorship}

\footnotetext{
${ }^{15}$ L. T. Hobhouse, Liberalism, (Oxford: Oxford University Press, 1981), 75.

${ }^{16}$ Some, of course, are not but this is something any objectivist, liberal or not, must concede.
} 
Self-authorship is the autonomous shaping of one's own life. Naturally, we can be the authors of our own lives only to a limited extent: self-authorship is the shaping of one's own life with the materials and resources one possesses. This is not to say that self-authorship is possible regardless of our circumstances. Sometimes, our materials and resources will be too few or too trivial or too similar to allow us to lead the life we prefer. One of the conditions of selfauthorship, as already mentioned, is the availability of options or opportunities. Furthermore, in order to be able to assess these opportunities and make choices we must have the necessary mental capacities. Since freedom should not be a privilege for the few mentally and intellectually gifted, these capacities need only be moderately developed. ${ }^{17}$ There is also a precondition to be met: we must not be deprived of certain basic goods, such as life, health, and bodily integrity. All that matters when our life is in danger, when we starve or when our health is poor is how to satisfy our basic needs for self-preservation, security, nutrition, the avoidance of suffering and pain etc. ${ }^{18}$ But even, finally, when all the aforementioned conditions are met, we can be prevented from shaping our own lives by external interference. This may -and most commonly will- include coercion or manipulation, although other kinds of autonomy-restricting interference are possible. ${ }^{19}$

\footnotetext{
${ }^{17}$ Adulthood is often employed as a criterion for separating those who possess the mental capacities from those who do not. This account is not committed to this view.

${ }^{18} \operatorname{Raz}(n 5,374)$ provides an extreme example of this situation by describing a hounded woman, who shares an island with a carnivorous beast. Her mind is constantly set on how to avoid being killed or injured by the animal. Self-authorship is impossible. In real life, people find themselves in less extreme but almost equally disabling situations. Extreme poverty, for example, can easily frustrate self-authorship very much in the same way the beast frustrates the hounded woman. In this sense, autonomy as self-authorship is an account of freedom that not merely allows but, in fact, requires certain very basic resources and services to be available to everyone. Perhaps this would include a basic income as well, especially in capitalist or quasi-capitalist societies -for an interesting proposal see Philippe Van Parijs, Real Freedom for All: What (If Anything) Can Justify Capitalism?, (Oxford: Oxford University Press, 1995). As I understand him, Van Parijs speaks of a 'real' freedom to make choices in the spirit of Hobhouse).

${ }^{19}$ For Raz's own description of these conditions see Raz, n 5, 369-278.
} 
I will touch upon issues concerning the mental capacity in section 2.2 and say a little about the importance of actively exercising our autonomy in section 2.3. I understand the satisfaction of a decent level of basic goods as a precondition for autonomy to require little defence. If all I can do is fight to stay alive or healthy there is very little room for selfauthorship. We cannot and do not blame people for failing to take control of their lives in such extreme circumstances. I must, however, clarify a few points regarding the remaining two conditions of self-authorship, namely the availability of options and freedom from external interference. These two aspects of self-authorship intertwine in a manner that heavily affects paternalistic legislation and policies.

\subsubsection{Coercion, manipulation and options}

As we saw, self-authorship heavily depends on decision-making. The autonomous person evaluates her options, assesses her plans and pursuits and, finally, decides what best suits her own lifestyle or needs. Coercion and manipulation undermine autonomy because they interfere with this decision-making process. It would take a long discussion to deal with all the issues raised by the philosophical literature on coercion. Let me roughly describe coercion as the means used in order to get another to do our bidding - to do as we tell her irrespectively of her wishes. This sketch leaves it open that coercion may not succeed - it is a 'means' rather than an achievement. It also means that physical compulsion is excluded. This description accounts for coercion's bad name: it is prima facie wrong to make other people act against their own will, at least because this kind of treatment seems to imply that they are inferior in some way, that they do not deserve a status equal to that of the coercer. The same, more or less, applies to manipulation, since it 'perverts the way [a] person reaches decisions, 
forms preferences or adopts goals' ${ }^{20}$ To make things even worse, manipulation, contrary to coercion, works better when its goals are not transparent. The manipulator would have us believe that we make our own minds by distorting the reality of our situation.

These very general points about coercion and manipulation may be rather uncontroversial but the more substantial point that coercion and manipulation crucially restrict autonomy as self-authorship is not. Making our own decisions may be essential to self-authorship but making decisions means, ceteris paribus, choosing among several available options. But we have already conceded that all we need to be autonomous is an adequate range of options. It follows that, as long as our options remain adequate, coercion and manipulation may be used to exclude a given option. But, surely, to say that my autonomy is not restricted when I am not allowed to choose volleyball as a hobby simply because there are other sports to choose from is profoundly counterintuitive.

I will say more about what is wrong with interfering with people's decision-making later, in my discussion of ethical autonomy. At this point, I merely want to address the concern that self-authorship may be ill-equipped to protect people's options. This is a potentially devastating flaw that would justify Berlin's concerns: the moment we allow the state to interfere with our options for any reason other than the protection of everyone's negative freedom, we open the door to oppression. Those who believe that freedom is a natural or absolute right with a purely negative aspect can safely rely on the harm principle to protect the traditional liberal values of individualism, authenticity, self-development etc. When freedom has a positive aspect, as happens in the case of self-authorship, the state is, in principle, justified in interfering with people's options and this could very well include

\footnotetext{
${ }^{20}$ Raz, ibid., 377-8.
} 
manipulating their sets of options in order to push them towards (or away from) preselected lifestyles. If what we need to be free is 'an adequate number of options' and personal wellbeing is a legitimate concern of a liberal legislator, what stops the state from removing the options it considers non-valuable so long as it maintains an adequate set? Negative freedom may end up being merely nominal freedom but positive freedom of this kind may result in no freedom at all.

Those who do not believe that autonomy is valuable qua autonomy (i.e. that autonomous decision-making is valuable for its own sake) find it very difficult to meet this challenge. Raz, for example, resorts to the negative symbolism of coercing or manipulating others ${ }^{21}$ and the indiscriminate nature of criminal legal sanctions that tend to cut off more options than initially intended. ${ }^{22}$ If the latter point were true, paternalistic criminal legislation would be out of the question. But, clearly, it is not: there are many types of criminal sanctions that stay clear from the options they do not specifically target. ${ }^{23}$ Fines and electronic tags are obvious examples. Nor is it true that coercion necessarily implies contempt or disrespect for the coerced. Like the father that threatens to punish his son because he loves and respects him, the paternalist may be justified -in fact, compelled- to employ coercion in order to save his fellow citizens from harm. ${ }^{24}$ Would it be enough to argue, as intend to do in this essay, that autonomous decision-making is intrinsically valuable and, therefore, any external interference is, in principle, regrettable? No, because autonomy is not lexically prior to all other values: it can

\footnotetext{
21 lbid, 378.

22 lbid, 418-9.

${ }^{23}$ Wojciech Sadurski, 'Joseph Raz on Liberal Neutrality and the Harm Principle', (1990), Vol 10 Oxford Journal of Legal Studies, 132 and John Stanton-Ife, 'The Limits of Law' in the Stanford Encyclopedia of Philosophy, (2006) Section 4, <http://plato.stanford.edu/entries/law-limits/>, accessed 7 September 2011. 24 John Finnis, 'The Legal Enforcement of Duties to Oneself: Kant v. Neo-Kantians', (1987), 87 Columbia Law Review, 433. Finnis goes on to explicitly include the coercive 'discouragement' of (even self-regarding) actions and dispositions that are injurious to personal well-being.
} 
and ought to be restricted in certain circumstances. In fact, we have already conceded that harm to others is not the only good reason for this kind of restriction by admitting that there is a real conflict between autonomy and well-being that needs to be resolved. So, how can we rescue our options from the oppressive hand of liberal paternalistic government?

The first answer to this question is that a liberal state is deeply committed to value pluralism. It should strive to ensure that the ways of life chosen by its citizens are not threatened unless there is no alternative. Autonomy as self-authorship requires that options are protected or made available by the state and that people should be allowed to make their own decisions. Any kind of interference with this process to the end of usurping it is hostile to self-authorship and, as we will see in section 4, incapable of making people's lives better. The second answer reminds us that self-authorship is a value realised by various different selves. In other words, individuals do not shape their lives by having adequate options; they shape them by making specific choices. Blocking an option may make no difference to the adequacy of options as a condition for self-authorship but it can -and often does- make a significant difference to the options the coerced individual has at her disposal. On the one hand, from an agent-relative perspective, one's options may be inadequate not because they are too few or valueless but rather because too few of them are appealing to the chooser. ${ }^{25}$ So, if I only want to become a soldier or a priest and both are ruled out (coercively or otherwise), as it used to be the case for women in many countries until recently, my options fall bellow adequacy despite the fact that hundreds of other jobs are available. On the other

\footnotetext{
${ }^{25}$ John Gardner, 'Prohibiting Immoralities', (2007), Vol. 28 (6), Cardozo Law Review, 2616. So, a person must have 'at least some options that are, from his point of view, worthy of choice' so that he can 'develop his talents and capacities' (Steven Wall, Liberalism, Perfectionism and Restraint, (Cambridge: Cambridge University Press, 1998), 141-142). This need is even more pressing when a person has committed time and effort to a particular option (Raz, n 5411 and Wall, ibid, 143).
} 
hand, every time I am coerced to abandon or choose an option, the life I lead is less mine, less of my making. And when the law aims at this interference (i.e. when the coercion is not the indirect result of a law which seeks to achieve some other goal - that is, when it is paternalistic in scope), I am entitled to feel that I am the victim of a hostile intervention which seeks to alter my set of opportunities. In doing so, the law deliberately imposes a disadvantage on me in order to get me to choose or abandon a certain option. ${ }^{26}$ It is one thing to say that we do not need every possible option in order to be autonomous; it is another to say that an option we cherish may be removed without restricting our autonomy. Admittedly, people who cannot pursue a professional career in American football because this particular sport is not played professionally in their countries cannot complain that they cannot author their own lives, ${ }^{27}$ but people who are not allowed to pursue an option that is -or can easily becomeavailable in their society, will rightfully complain.

One final point that is also relevant to state paternalism (although it may not be obvious at this stage): coercion and manipulation are not the only kinds of external interference with personal autonomy. In some cases, our decision-making is usurped without resorting to coercion or manipulation. Consider the following examples.

- A mother buys a jar of candy for her children. Knowing that they will finish the candy in one seating if they have the opportunity, she hides the jar on the top shelf and secretly takes out some candy every time she feels they should have some.

- Jane's mother suffers from a serious heart condition and has to spend a lot of time at home. She recently discovered the joy of watching films in her new television set and

\footnotetext{
${ }^{26}$ Grant Lamond, 'The Coerciveness of Law', (2000), Vol. 20, (1) Oxford Journal of Legal Studies, , 61-62.

${ }^{27}$ They can, of course, regret the fact that they live in such a country and, perhaps, seek such a career elsewhere. This is a side-effect of having easy and almost unrestricted access to information. We know alternative careers or lifestyles exist, even if they are foreign to our own ways, customs or circumstances. The adequacy of options requirement rules out the absurd conclusion that autonomy is unattainable in such cases.
} 
the employees from the local video store are happy to deliver the films to her so that she does not have to make the trip too often. Jane is aware that her mother knows almost nothing about films and that she relies on the store owner to recommend films to her. So, she asks him to never recommend The Exorcist to her mother fearing that her weak heart won't stand the horror.

- John is seriously ill and cannot communicate with his doctors. He requires immediate kidney transplantation. His wife knows that John is against transplantation because he thinks that it is immoral to take another human being's organs, under any circumstances. She says nothing and simply signs the papers for the operation.

John, Jane's mother and the children have something in common: decisions are made for them, without their consent or participation. They are not coerced or manipulated in any way. They are not presented with a threat or a lie. Nonetheless, their decision-making is usurped: John would have probably refused the transplantation (or succumbed to the pressure and acquiesce); the children would have eaten all the candy (or respected their mother's advice); and Jane's mother could have developed a liking for horror films (if she had ever come across the option of watching The Exorcist). All of them can reasonably claim that their autonomy was not respected, simply because someone else decided for them. And they can make this claim even if they would have ended up making the same decision anyway.

\subsubsection{The instrumental value of self-authorship}

So, this is a rough sketch of autonomy as self-authorship - one drawn with paternalism in mind. The pressing question that naturally follows is what is its value? The obvious answer is that self-authorship is valuable because it is essential for personal well-being. It would be premature to explore this point further without a concrete account of well-being in mind. I 
will merely make some preliminary remarks that I regard as relatively uncontroversial. Personal well-being concerns itself with the life of the person whose life it is. ${ }^{28}$ In this sense, whether one leads a good and fulfilling life (whatever that may be) partly depends on one's ability to shape it according to one's convictions, values, preferences etc. This does not imply that every aspect of the good life must be autonomously shaped: there may be things that make our lives good even if we deny their value. ${ }^{29}$ On the other hand, we may find ourselves flourishing in areas we literally 'found ourselves in', through parental encouragement, educational guidance and so on. Assuming that these activities or projects cannot make our lives better without our voluntary participation (like, for example, marriage or employment), we still may come to endorse them at a later stage. If we do, they will contribute to our wellbeing; if we do not, they can still count as achievements but they will not make our lives better from our point of view. In these cases, autonomy works as a safeguard: the autonomous person can change her mind or challenge what has been delivered to her by her parents and teachers and opt out of a way of life she no currently endorses. In the sense just described, autonomy is instrumentally valuable: it is essential for personal well-being, without being all there is to living well. The good life is, of course, of unquestionable value.

\subsection{Metaphysical autonomy}

It is tempting to conclude a discussion of autonomy as self-authorship without touching upon its complex metaphysics. In fact, some theorists choose to explicitly exclude 'metaphysical autonomy' from their analysis: personal autonomy is just a 'character ideal', as Steven Wall put it in his distinctly Razean account of personal autonomy. ${ }^{30}$ This, I think, is easier said than

\footnotetext{
28 Joseph Raz, 'The Role of Well-Being' (2004), Vol. 18, Philosophical Perspectives, 269.

${ }^{29}$ For a brief but enlightening discussion of this point that reaches different conclusions than mine see Ronald Dworkin, 'Sovereign Virtue: The Theory and Practice of Equality, (Harvard University Press, 2000), 216-7.

${ }^{30}$ Wall, n 25, 127-128.
} 
done. For example, despite his disclaimer, Wall speaks of autonomous people who make 'something out of their lives according to their own understanding of what is valuable and worth doing' ${ }^{31}$ As I understand him, Wall says that you cannot be autonomous unless you can identify your life with something you consider valuable. This seems to make a lot of sense: if you cannot have such an understanding, how can you claim that this is your life, a life of your own making? In the context of self-authorship, it is useful to compare one's life with a book: unless there are certain central ideas running through the book or large parts of it, the final product will make little or no sense. As a result, the author will not even recognise it as her own work: 'this is not what I really wanted to write', she will say. The same applies to autonomous living: we must see some projects through, adopt (sooner or later) certain principles, live according to one or more plans. Of course, this does not mean that we cannot change our minds. But, clearly, those who change their minds all the time do not know what they really want.

In any case, Wall is right to be cautious: we would be well advised to stay away from the thorny issue of free will. ${ }^{32}$ We must, however, become somewhat more clear regarding selfauthorship's concern for making plans, pursuing projects and taking up commitments, partly because this aspect of autonomy is particularly valuable. Raz's account seems to rely on an implied dichotomy between a higher and a lower order of goals. ${ }^{33}$ Twice in the Morality of

\footnotetext{
$31 \mathrm{lbid}, 128$.

32 Or practical reasoning. Raz offers a thorough discussion of his view on ordinary and exclusionary reasons in his 'Facing Up: A Reply', (1989), 62 Southern California Law Review, 1153-1215.

${ }^{33}$ Similar views on the significance of higher order preferences or qualities can be found in Charles Taylor, 'What is Human Agency?' in Philosophical Papers (Cambridge: Cambridge University Press, 1985) and Gerald Dworkin, 'The Concept of Autonomy' in The Theory and Practice of Autonomy, (Cambridge: Cambridge University Press, 1988).
} 
Freedom ${ }^{34}$ he refers, with approval, to the work of Harry Frankfurt ${ }^{35}$ on the subject. Secondorder goals are important. Projects are also important and people must identify with them. Autonomy requires a certain level of integrity, i.e. of loyalty to one's choices. A person fails to shape her own life when she is driven by forces she cannot control or motivated by desires she detests, when she pursues goals she does not really value. ${ }^{36}$

Value is a key word in this discussion. Raz explicitly separates simple 'desires' from more settled kinds of 'wants'. To want something can mean that we embrace it as a project, a pursuit or a relationship. ${ }^{37}$ As we saw, Wall's account of self-authorship also relies on the ability of people to do what they consider valuable. In this sense, the dichotomy may be closer to the one Watson is proposing: to value is one thing, to desire is another. Generally speaking, desires do not concern themselves with what we understand to be good and valuable. ${ }^{38}$ Laura Waddell Ekstrom has attempted to reformulate Frankfurt's principle by adding an 'evaluation clause': it is judgments of worth that make some desires authentic and, therefore, indicative of the person's true will. ${ }^{39}$ It is the authenticity of these motivating values or evaluated desires that grants them this special status for self-authorship: they define our lives and, without them, there can be no identification with one's own life. ${ }^{40}$ Again, this does not imply that people cannot change their minds or hesitate to make a decision when two or more of their values are in conflict. It simply means that, in normal circumstances, we adopt plans, engage

\footnotetext{
${ }^{34}$ Raz, n 5, 294, 382.

${ }^{35}$ Especially Harry Frankfurt, (1971), 'Freedom of the Will and the Concept of a Person', Vol. 68, (1) The Journal of Philosophy, 5-20.

${ }^{36}$ Raz, n 5382.

37 Ibid, 389.

${ }^{38}$ For an enlightening discussion see Gary Watson's seminal paper 'Free Agency', (1975) The Journal of Philosophy, Vol. 72 No. 8, 205-220.

${ }^{39}$ Laura Waddell Ekstrom, 'Autonomy, Alienation and the Self' in P. French and H. Wettstein eds. Free Will and Moral Responsibility, (Boston MA and Oxford UK: Blackwell Publishing, 2005), 45-67.

${ }^{40}$ See Thomas E. Scanlon, 'Reasons and Passions' in Sarah Buss \& Lee Overton (eds.), Contours of Agency: Essays for Harry Frankfurt, (MIT Press, 2002).
} 
in relationships etc because we consider them valuable and that, when we consistently fail to commit to these projects, ${ }^{41}$ our conduct is not that of an autonomous person. It is because I truly value music that I want to learn how to play the piano; to this end, I take the bus to the conservatory every afternoon. I could just have some drinks with my friends instead but I consider this routine meaningless and a waste of time. If I get off the bus before I reach the conservatory because I cannot resist my craving for a few drinks, I fail to act as an autonomous person, even if my decision was 'free', i.e. not imposed by another person. And if this is what I normally do every time I adopt a project, I will not be the author of my life. Obviously, this is by no means a complete discussion of the implicit dichotomy that runs through the concept of self-authorship. My only purpose was to draw a rough sketch of what I understand to be a defensible view of the metaphysics of self-authorship. Such a view seems to depend -to an extent- on having a certain degree of free will (as described in the work of Watson) because otherwise it would be impossible to see through all those projects that define the kind of life we intend to lead. Whether we are truly committed to the projects we consider valuable is, of course, a matter of degree. For the purposes of this essay, all we need to remember is that self-authorship is impossible only when our failure to commit to what we value is extreme.

\subsection{Ethical autonomy}

\subsubsection{Making choices and being responsible}

The autonomous person described in the previous section should not be conceived as a highly intellectual being with the critical self-reflection of a Socrates..$^{42}$ Most people go through a process of evaluating their options with reference to their deep-rooted beliefs and ideals. And

\footnotetext{
${ }^{41}$ After all, projects and plans involve a certain kind of commitment to action (see Michael E. Bratman, Intention, Plans and Practical Reason, (Center for the Study of Language and Information, 1999), Chapter 3).

42 Pace Wall, n 25139.
} 
many people abandon their values and adopt new as they go, with no damage to their autonomy. This, however, is only the first step. It is not hard to imagine a person who reflects on her values and adopts goals with which she identifies and yet does nothing to realise. Deciding what one values the most requires no real action - it can be done within the walls of a prison cell. Once this process is over ${ }^{43}$ we must set out to pursue our goals. Selfauthorship is an exercise concept: we must possess the spirit and vigour ${ }^{44}$ required to shape our own lives in practice. This means, firstly, that we must remain loyal to our cause rather than abandon it when we hit the first snag. Secondly, it means that we must decide how to materialise our plans. Normally, we will have several options to choose from. If we keep making the wrong choices (due to ignorance, laziness, hastiness etc) we will end up with a life that is a far cry from what we wanted it to be. Obviously, to reach this point, one's failure must be consistent and extreme.

Of course, with autonomy comes responsibility. The autonomous person is responsible in two easily distinguishable senses. First of all, she has the responsibility to take her life into her own hands, not to subordinate herself to the will of another, be it the government or another human being. There will always be influences and paradigms to follow but, all in all, autonomy requires that we accept this responsibility. ${ }^{45}$ Assuming that the conditions for self-authorship are met, we must assume another responsibility: that of the life we end up leading, since it is a life we shaped ourselves. We can be held responsible for something when we deserve praise or blame for it. ${ }^{46}$ An autonomous life can be good or bad,

\footnotetext{
${ }^{43}$ Obviously, this is only an expression: in real life, adopting goals and setting out to pursue them intertwine and affect each other (see Raz, n 5 389).

${ }^{44}$ I am borrowing the term from Wall, $\mathrm{n} 25,138$.

${ }^{45}$ Ronald Dworkin, Is Democracy Possible Here?: Principles for a New Political Debate, (Princeton University Press, 2006), 17.

${ }^{46}$ Galen Strawson, Freedom and Belief, (Oxford: Clarendon Press, 1986), 1.
} 
fulfilling or empty. Whatever we judge it to be, its quality reflects on the character and skill of its author.

\subsubsection{The intrinsic value of autonomy}

The preceding remarks bring us back to the discussion of the value of autonomy. It is at this stage of the discussion that the brief and sketchy analysis of the metaphysics of selfauthorship and its relation to responsibility become most useful. Having a character in the active sense just described ${ }^{47}$ and assuming responsibility for the choices we make and the life we lead seems valuable in itself. I have already argued that autonomy has instrumental value, as a contributor to personal well-being. But something can be both instrumentally and intrinsically valuable. By intrinsically valuable I mean valuable for its own sake. Raz, on whose account I have heavily relied so far, argues against the idea that autonomy is valuable qua autonomy. To support his view he points out that, clearly, autonomous wrongdoing is (morally) worse than non-autonomous wrongdoing. If the autonomous act is less valuable (in fact, more blamable) than the non-autonomous one, how can autonomy be valuable for its own sake? While this is a correct assessment of the wrongful act as well as the wrongdoer, it says nothing about the value of autonomy. As Robert George puts it, 'if something is intrinsically valuable, its realisation in immoral acts does not negate its value'. ${ }^{48}$ The same applies to the autonomous life or the autonomous person: it does not necessarily follow from the intrinsic value of autonomy that the life or the person related with autonomy must gain

\footnotetext{
${ }^{47}$ Wall, $\mathrm{n} 25,147-148$.

${ }^{48}$ Robert George, 'The Unorthodox Liberalism of Joseph Raz', (1991), Vol. 53 (4), The Review of Politics, 665. The value of autonomy is not reduced by the fact that it can lead to bad or even catastrophic decisions either. This explains why autonomy is not 'overvalued' (for a defence of this point see Sarah Conly, Against Autonomy: Justifying Coercive Paternalism, (Cambridge: Cambridge University Press, 2013).
} 
in value as well. ${ }^{49}$ Nor is it true, as Kymlicka thinks, that from the intrinsic value of autonomy follows the absurd conclusion that we must exercise free choice as much as we can, even in the most trivial matters, because 'the more free we are the more valuable our lives will be'. ${ }^{50}$ Self-authorship heavily depends on making long-term projects and being loyal to them. This is exactly the opposite of waking up every morning and choosing what kind of person we want to be all over again. And, of course, spending a lot of time and energy to make decisions on trivial things, like which fork to use at dinner, is also injurious to self-authorship because it detracts us from more valuable pursuits. ${ }^{51}$

If making autonomous choices is valuable regardless of the choice made or the outcome of our autonomous action, there is good reason to believe that autonomy is valuable qua autonomy. Love, friendship and health are valuable in this sense, because they are wanted and intended irrespectively of what they produce. ${ }^{52}$ Courage and bravery can be used for the worst of purposes but they are still admirable traits. That autonomy seems to have a kind of value that does not depend on the outcome of its exercise is manifest in our treatment of a personal success that was not the result of an autonomously chosen pursuit. If $A$ autonomously chooses to $\mathrm{X}$ and succeeds in X-ing, her success is seen in a much favourable light than the same success of B, who had X chosen for her by someone else. Assuming that

\footnotetext{
49 Jeremy Waldron, 'Autonomy and Perfectionism in Raz's Morality of Freedom'1128. Of course, Raz believes that autonomy is intrinsically valuable as a constituent element of the good life. To the extent that autonomy contributes to the personal well-being, its value is not intrinsic but instrumental. On this point, see a similar and more extensive critical response in Donald Regan, (1989), 'Authority and Value: Reflections on Raz's The Morality of Freedom', 62 Southern California Law Review , 1084.

${ }^{50}$ Will Kymlicka, Liberalism, Community and Culture, (Oxford: Clarendon Press, 1991), 49.

${ }^{51}$ Thomas Hurka, Perfectionism, (Oxford: Oxford University Press, 1993), 151.

${ }^{52}$ Robert Young, Personal autonomy: beyond negative and positive liberty, (Saint Martin's Press Inc., 1986), 2930.
} 
$X$ makes both A's and B's life good, what we value in A's case cannot be the good life. It must be her autonomous choosing for its own sake. ${ }^{53}$

It may be the intuitively appealing value of rational self-direction we detect in A's conduct. ${ }^{54}$ It is sometimes said that it is the value of the exercise of our mental abilities that endows the capacity with what it is worth. ${ }^{55}$ The more modest way to put it is that the capacity we are discussing is the ability for rational choice, whose exercise is opposed to 'acting without reasons or for conjuring action commitments out of nowhere' ${ }^{56}$ Every time we face a decision, we enter a process of critical reflection, evaluation and foresight that, one step at a time, shapes the kind of life we choose to lead. If we decide to buy a fast car, for example, instead of saving money for a house in the country, we take a step towards an adventurous life and away from relaxed and quiet living. Remember our earlier discussion of wants, desires and values: if we are to be autonomous, we need a critically reflective self ${ }^{57}$ to help us put aside our irrational side and satisfy our more important volitions and values rather than passing desires. ${ }^{58}$ Virtues like authenticity (i.e. the reflective endorsement of our desires), ${ }^{59}$ integrity ${ }^{60}$ and self-creation ${ }^{61}$ are, to different extents, manifestly exemplified in the exercise of our ethical autonomy. Again, this need neither imply nor necessarily entail the unappealing image of a person suffocating in an austere personal regime of infinite self-reflection and

\footnotetext{
${ }^{53}$ Wall, n 25, 147.

${ }^{54}$ George Sher, Beyond Neutrality: Perfectionism and Politics, (Cambridge: Cambridge University Press, 1997), 50 .

${ }^{55}$ Raz, n.5, 372.

${ }^{56}$ Stanley Benn, A Theory of Freedom, (Cambridge: Cambridge University Press, 1988), 179.

${ }^{57}$ Richard Arneson, 'Autonomy and preference formation', in In Harm's way, Essays in Honor of Joel Feinberg, ed. Jules Coleman and Allen Buchanan (Cambridge University Press, 1994), 46.

${ }^{58}$ Gerald Dworkin, The Theory and Practice of Autonomy, (Cambridge: Cambridge University Press, 1988 ), 20.

59 John Christman, 'Constructing the Inner Citadel: Recent Work on the Concept of Autonomy', 99 Ethics, (1988), 109-24.

${ }^{60}$ In the sense of the term adopted by Raz, i.e. as a the identification with one's goals and the loyalty to one's projects and relationships (Raz, $n$ 5, 383).

61 Joel Feinberg, 'Autonomy' in The Inner Citadel: Essays on Individual Autonomy ed. John Christman (Oxford University Press, 1989), 35-6.
} 
fanatic commitment to what used to be carefully thought out projects. It is an almost inescapable fact of life that some decisions are not the product of critical reflection: we wear a tie at work because 'everyone does', we eat red meat because 'it is Sunday' and so forth. The intrinsic value of ethical autonomy does not entail that we must exercise it all the time as already mentioned, this would be against the very meaning of authoring one's own life.

I think that another crucial point here is that $\mathrm{A}$ is assuming responsibility for her life. She does not rely on someone else to make decisions for her and, therefore, does not reserve the right to complain that 'it was not (entirely) her fault', if things go wrong. If things do go wrong, it will be, other things being equal, her fault. In addition, when she decides to pursue $X$, she also decides not to pursue $Y, Z$, etc. She evaluates her options and expresses here own understanding of what the world has to offer as well as of what she wants from the world. ${ }^{62}$ If these remarks make sense, the exercise of self-authorship in a meaningful and reflective manner is valuable not merely because it is an instance of rational self-direction but also because it produces moral responsibility. This kind of responsibility does not depend on the outcome of the autonomous choice or on how we use our autonomy in general but rather on the very exercise of self-authorship. If self-authorship itself is the source of this responsibility, we can only conclude that autonomy is valuable qua autonomy. Of course, the two sources of intrinsic value just discussed are not independent of each other. The exercise of rational self-direction is a prerequisite for assuming responsibility for one's choices; and a proper understanding of the responsibility that comes with self-authorship is part and parcel of the process of turning to our reflective selves in order to authentically author our lives.

\footnotetext{
${ }^{62}$ Hurka, n 51, 150.
} 


\section{Paternalism vs. autonomy}

\subsection{Restricting self-authorship}

Now that we have a rough but -hopefully- sufficiently clear sketch of self-authorship in mind, I must return to my claim that autonomy as self-authorship describes the freedom-restricting effects of paternalism better than any other account of freedom. Let us remember the three categories of autonomy-violating action: coercion, manipulation and the usurpation of decision-making. When the restriction of autonomy is in the service of the well-being of the person whose autonomy is restricted, we can speak, respectively, of three types of paternalism: coercive paternalism, manipulative paternalism and paternalism that usurps decision-making or, for convenience, decisional paternalism. Autonomy as self-authorship is the only understanding of freedom that accounts for all three types of paternalism. Freedom as the absence of constraint ${ }^{63}$ is, clearly, not what the paternalised is denied: first of all, she can resist coercion and do what she wants to do anyway; and, of course, decisional paternalism does not restrict freedom. Liberty of action suffers from the same problem: the unconscious patient has none and yet he is treated paternalistically when his views on transplantation are conveniently overlooked by his wife. I can now confess that all the examples of decision-making usurpation were carefully selected to be potential instances of paternalism. So, when a decision is made for us, with our own good in mind, we will be right to think that we are treated paternalistically. Our freedom and liberty of action do not necessarily suffer but our autonomy does, because autonomy as self-authorship is based on making our own decisions and shaping our lives through projects and commitments. In some

\footnotetext{
${ }^{63}$ Or primitive freedom, as Bernard Williams put it in his 'From Freedom to Liberty: The Construction of a Political Value', (2001), Vol. 30 (1) Philosophy and Public Affairs, 3-26.
} 
cases, we will never even find out that the option removed or hidden away was ever available. In others, we will not have the opportunity to act according to our deep-rooted convictions. The paternalistic intervention may be justifiable in some of these cases, but it is paternalism nonetheless.

Autonomy as self-authorship is also equipped to explain why the paternalist does not always act against our will. As we saw, self-authorship relies on evaluating our options, making plans and staying loyal to them. In this sense, getting off the bus before the conservatory stop to drink with my friends is what I want -right here and right now- but it is against my project to study music. Finally, autonomy explains how indirect paternalism (i.e. the interference with a third party for the paternalised's own good) affects the freedom of the paternalised: the purpose of such an interference is essentially to remove an option from A's scope by directly interfering with B who can provide the option in question (a typical example is the ban on the sale of certain dangerous substances one cannot simply make in one's own home).

\subsection{State and legal paternalism in particular}

The archetypical paternalistic law is not particularly sophisticated. It is, more often than not, a criminal law that communicates a coercive threat: 'if you use drug $\mathrm{X}$, you will be prosecuted and punished'. There is little left to be said about this paternalistic means: the literature offers many examples and just as many illuminating discussions. I only wish to return to Raz's worry that criminal paternalistic legislation can cut off many valuable options. As already mentioned, this is not necessarily true, since there are sanctions that, despite their coercive nature, can be limited to targeting only the option in question. Fines are an obvious example: so long as they remain reasonable, fines do not affect our ability to pursue options other than 
the one prohibited by the law that imposes them. In addition, modern technology offers alternative methods of sentencing that guarantee the offender's ability to continue with his life. Electronic tags, for example, are often used to monitor the offender's movements without restricting any options other than the one that should be restricted. However, there is a lot of sense in reminding that self-authorship is not attainable without options. So, if the paternalist is serious about her claim that she wants to help the paternalised, she ought to make sure that the latter's options are not restricted without a compelling reason. This means that sanctions with devastating effects on the availability of options, like imprisonment, are prima facie very problematic. The same applies to excessive fines or alternative methods of sentencing that severely affect the paternalised's options. I will return to these points before concluding this essay.

Decisional paternalism may seem rather unlikely in the public domain. People who are close to us are likely to make decisions on our behalf but it is not immediately obvious how the state or the law can do the same. Interestingly, decisional state paternalism is much more common than most seem to think. The removal of an option, for instance, is not uncommon as paternalistic practice. Everyone who has watched a movie that deals with the Prohibition in the USA is aware of the American government's effort to effectively remove all alcohol from the country by destroying distilleries and disposing of any alcohol confiscated. Contemporary anti-drug laws include similar provisions regarding illegal drugs and laboratories. Of course, these methods are usually impractical but the paternalistic goal is easier to achieve when the state itself is the provider of the option in question. Consider, for example, same-sex marriage: unless the legislator creates or acknowledges the institution of same-sex marriage, the option virtually does not exist. It is difficult to say whether the rationale for the non- 
recognition of same-sex marriage is paternalistic or moralistic. But it is evident that governments can make an option unavailable on paternalistic grounds and that they have attempted to do so in the past. In a similar manner, the state can effectively withhold information that may tip the balance in favour of a harmful option. In the 1950s, many governments campaigned against the use of marijuana claiming that, according to scientific research on the subject, the drug made young people irrational, mentally unstable, even immoral. These findings have been widely disputed and, in some cases, discredited but it is highly unlikely that governments will ever campaign to set the record straight. But the paternalistic work is already done, since a conclusion regarding the harmfulness of a drug is not for us to reach - it is a job for the experts. Again, these methods are not particularly effective in our time, since most people have access to all the information they need. Let us not forget, however, that governments have the advantage of authority: when the government endorses a position, people have more reasons to endorse it as well. In addition, we must not overlook the importance of government control over the curriculum of public schools and universities, since many things we learn at an early age remain unchallenged for the rest of our lives. There is no room for a real discussion of these points here but there is no doubt that they should present many intriguing paternalism-related challenges in terms of self-authorship. ${ }^{64}$

Some of the preceding remarks may ring a familiar bell: they seem to involve a fair degree of manipulation. A state that deliberately exaggerates the harmful effects of a drug can certainly be accused of manipulative paternalistic practices. Clearly, it is wrong for any government to lie to its citizens but we would be hard pressed to find any serious instances

\footnotetext{
${ }^{64}$ I discuss these issues in more detail in my 'Educative Perfectionism', working paper, available on request.
} 
of this kind of manipulative paternalism in modern liberal states. However, manipulation may not be completely out of the picture yet. The unprecedented popularity of behavioural economics is affecting several areas of government policy, including the protection of personal well-being. In their famous contribution to the debate, Richard Thaler and Cass Sunstein proposed a brand of libertarian paternalism that promises much more than I have promised in the introduction of this essay. They claim that, by properly exploiting well-known biases that affect human reasoning, the government can produce guaranteed paternalistic results without restricting individual freedom. ${ }^{65}$ It is on the very first page of their book, however, that we find a discomforting similarity with the candy jar example. The first example of how libertarian paternalism would work in practice is that of a cafeteria manager who places the foods on the shelf in a manner that 'makes' people choose healthier dishes for their lunch. Crudely put, the cafeteria manager should place the healthy options at eye level because people tend to select things they see rather than things they do not (easily) see. ${ }^{66}$ But, if this method is as effective as Thaler and Sunstein claim, it is not, at least prima facie, substantially different than hiding the candy jar from the children. If the burger I was craving all day is hidden on the lower shelf and this makes me select a salad instead, do I have more freedom to choose the salad than the child does to choose the candy? Even more worryingly, some of the behavioural tools in the service of the paternalistic state (defaults, for example) have been shown to secure almost absolute compliance in issues that divided the public before the implementation of the new rule. It is not surprising that this kind of 'choice architecture' is seen as inherently manipulative by some theorists. I will look at these points in more detail in the last part of my discussion. At this point, my goal is to point at the

\footnotetext{
${ }^{65}$ Richard E. Thaler and Cass R. Sunstein, Nudge: Improving Decisions about Health, Wealth, and Happiness, (New Haven and London: Yale University Press, 2008).

${ }^{66}$ Ibid., 1.
} 
possibility of paternalistic policies and legislation (after all, most of these policies require legislative backing) that restrict autonomy as self-authorship without resorting to coercion. ${ }^{67}$

\section{Well-being}

\subsection{The concept and how paternalism can be efficient}

The main purpose of this discussion, we must remember, is to explore the conflict between autonomy and well-being that is inherent in paternalism. If autonomy as self-authorship were only valuable when exercised in pursuit of the good, then the paternalist could have his way with all those bad and valueless choices people tend to make. If, however, autonomy is also intrinsically valuable, we have to take into account the fact that every restriction of autonomy is regrettable. But this does not mean that it is never justified: autonomy is neither the only valuable thing nor lexically prior to all other valuable things. So, what we need is a method of balancing: we must show under which conditions autonomy ought to retreat for the sake of a greater gain. If all we can say is that well-being is important and must be protected, we may very well end up with a slippery slope, because autonomy is not the only contributor to the good life. So, why not use coercion to secure other components of well-being? ${ }^{68}$ Raz's account is ill-equipped to meet this challenge, because it identifies well-being with the successful pursuit of goals and projects. ${ }^{69}$ This is, perhaps, why he thinks that a general rule, either in favour or against paternalism, does not make any sense. I submit that we can safely adopt

\footnotetext{
${ }^{67}$ I mean direct coercion: most laws contain a coercive element, since we cannot violate them without consequences. But the coercion I am discussing here is the kind that aims to secure compliance with a paternalistic measure.

${ }^{68}$ For this line of criticism see G. Dworkin, (1988), 'Review: The Morality of Freedom', Ethics, Vol. 98, No. 4, 851.

${ }^{69}$ Admittedly, Raz's discussion of the distinction between well-being and self-interest in the Morality of Freedom is a bit confusing (See Roger Crisp, 'Raz on Well-Being', (1997), Vol.17, (3) Oxford Journal of Legal Studies, 500-505). As I understand his point, the satisfaction of basic needs is good for our self-interest, not our well-being, unless we make it our goal to satisfy them.
} 
such a rule, provided that we have a concrete notion of personal well-being in mind that can, under certain conditions, outweigh autonomy, despite the latter's intrinsic value. The discussion that follows will also meet the challenge of efficiency by pointing at the aspect of well-being that can be protected/promoted by paternalistic means.

Our first job, then, is to provide a general (but not too general) description of what a good life contains. I think that Martha Nussbaum offers an account of capabilities and functionings that captures most of what we understand as the most important human goods. Here is her list: life; bodily health; bodily integrity; senses, imagination and thought; emotions; practical reason; affiliation; other species; play; control over one's political and material environment. ${ }^{70}$ I think that most of us would have no quarrel with this list but I do not intend to treat it as exclusive or exhaustive of what we understand a good life to contain. I have opted to rely on this list for two reasons besides its intuitive appeal. Firstly, because it cannot be accused of elitism: Nussbaum seeks to provide governments with a rule of thumb so that they can fulfil their duty of 'making people able to pursue a dignified and minimally flourishing life' ${ }^{71}$ Secondly, Nussbaum treats these goods (or functionings, as I understand the two terms to have roughly the same meaning) as threshold notions. That is, she appreciates the difference between having the ability to make decisions on the one hand and writing scholarly articles on practical reasoning on the other: only the former is a sine qua non for a good life. ${ }^{72}$

\footnotetext{
${ }^{70}$ Martha Nussbaum, Creating Capabilities: The Human Development Approach, (Cambridge, Mass. and London: Harvard University Press, 2011), 33-34.

71 lbid, 23-33.

72 Interestingly, Nussbaum's scheme has plenty of room for excellence: to say that governments should, before anything else, make sure that everyone enjoys a threshold level of all goods is not to say that they should not pitch for more once this level is secured. Of course, this account of well-being may, at least prima facie, be incompatible with certain ascetic lifestyles, which reject the value of some goods. I believe that this is not a decisive objection but developing this point would require a lengthy detour.
} 
Nussbaum initially supported the view that some of these goods (namely, health and bodily integrity) are so important that 'some interference with individual choice would be legitimate "up to a point"'. ${ }^{73}$ However, in a later contribution to the debate, she explicitly denounces paternalism, even when it seeks to protect as fundamental a functioning as health, 'because of the high value [she ascribes] to choice'. ${ }^{74}$ Nussbaum speaks of capabilities and the very notion of capability implies being allowed to choose how to go about one's own functioning. Therefore, her retraction is not surprising. However, capabilities seem to only make sense -and have the value attributed to them- if they can at least eventually turn into functionings. There would be nothing valuable or politically desirable in providing an individual with a capability knowing that she will never be in position to possess the functioning to which the capability paves the way. ${ }^{75}$ Amartya Sen's account of capabilities, on which Nussbaum is drawing here, is illuminating exactly because it points to the fact that not all people are able to gain access to certain basic functionings in the same way and with the same resources. But functionings are what we should finally care about.

Nussbaum's anti-paternalism seems to imply that free choice is essential to the realisation of all the functionings on her list. However, this is clearly not the case: one can realise the functionings of life, bodily health and integrity, the use of senses, imagination and thought, as well as maintain the basic ability for practical reasoning without freely choosing to do so. This is even more plausible in the context of a threshold account like Nussbaum's: if

\footnotetext{
${ }^{73}$ Martha Nussbaum, Women and Human Development: A Study in Human Capabilities, (Cambridge: Cambridge University Press, 2000), 95, my emphasis.

74 Martha Nussbaum, n 70, 26. Nussbaum claims that this is Sen's position as well. Nussbaum's antipaternalism is by no means absolute: it is justified in the service of dignity, which means that slavery contracts should be illegal, even when voluntary on the part of the 'slave' (ibid).

75 This is, roughly, Richard Arneson's position, see Richard Arneson, 'Perfectionism and Politics', (2000), Vol. 111, (1), Ethics, 60. In fact, Nussbaum herself seems to appreciate this point when she argues that 'in a sense, capabilities are important because of the way in which they may lead to functionings': see $n$ 70, 25.
} 
a basic amount of bodily health requires the use of all my limbs, I can enjoy this good even if I am not completely free to do as I please with them. So, if I am allowed to use them (or not use them if I choose) but not to cut them off or severely injure them, I will enjoy, other things being equal, bodily health even if I am coerced by the government, by means of the criminal law for example, to do or refrain from certain things in order to minimise the risk of injuring or losing my limbs. ${ }^{76}$ Surely, not all functionings are like that: there is no point in forcing people to care for animals, to engage in relationships, emotional attachments, work and play or to make plans. These goods can be realised only through active participation, only if we embrace and make them our own pursuits - only if we endorse them. The rest of the functionings on Nussbaum's list, to which we can also refer as 'all-purpose goods' or 'basic needs', are partly valued for their contribution to the realisation of other goods: the ability to rationally assess our circumstances is essential for adopting goals, the ability to use our senses and imagination may help us to find meaningful work, health gives us the rigor to participate in politics and so on. ${ }^{77}$ But this is not the only way in which they contribute to well-being: they are strong aspects of our well-being in themselves, as basic goods. They are too part of the good life, alongside the successful pursuit of valuable projects, even when we do not adopt them as goals. ${ }^{78}$ And as such, they are worthy of protection.

However, we should not overstate the distinction between goods that must be endorsed and actively pursued to be enjoyed and goods that need not: health and bodily integrity or the ability to make rational decisions and plans can be the objects of such pursuits

\footnotetext{
${ }^{76} \operatorname{Raz}(n 5,297)$ makes a similar point regarding the enjoyment of 'biologically determined needs'.

77 In a sense, these are 'all purpose goods': they seem to be valuable regardless of how one chooses to benefit from them in terms of goals, projects and pursuits. Nussbaum points out that health, bodily integrity, practical reason and (rather surprisingly) religious liberty are included in her list precisely because they contribute to many different pursuits ( $\mathrm{n} 70$, Appendix $B, 201$ ).

78 This is another way in which my account crucially departs from Raz's analysis, since Raz seems to reject this view (Raz, n 5, 296).
} 
as well. The Olympic athlete has made health her goal and actively pursues it. But, clearly, this is not a threshold level of health: it is much more than that, since the athlete's goal is a perfectly healthy and strong body - the kind of well-oiled machine that is, in a sense, a 'surplus to requirements' for those who are not after an Olympic medal. This is where Nussbaum's threshold approach becomes most useful thanks to its ability to account for the significance of an acceptable minimum of basic goods for the good life. Well-being requires the realisation of these goods at a threshold level below which a life ceases to be good. In the case of life, bodily health and integrity, the use of senses, imagination and thought and a basic ability for practical reasoning, we can reach this level without actively pursuing or endorsing these goods; the other goods on Nussbaum's list can only be realised through active and voluntary participation. But the former can also be adopted as goals ${ }^{79}$ (most commonly when more than just a threshold level is desired) and, when they are, they must also meet the endorsement ${ }^{80}$ condition, like any goal or pursuit. These points address the objection from efficiency, as they show that there is an aspect of well-being that can be effectively protected and promoted by paternalistic means.

\subsection{The balancing}

So, the value of basic goods lies in their significance for personal well-being: without them, it is highly unlikely that our life would be good for us. But at the same time, these basic goods are essential for autonomy as self-authorship: as we saw, a person who lacks a threshold level of the basic goods of bodily health and integrity cannot be autonomous, except in trivial matters that are not part of deliberate self-determination. The satisfaction of these needs is,

\footnotetext{
79 See also Raz, ibid, 295-297.

${ }^{80}$ A quick note regarding endorsement: we can endorse a project or relationship without thinking of it as perfect or with occasional discomfort. A doctor may endorse medicine and still wish it were not part of her job to announce a patient's death.
} 
in a sense, a precondition of autonomy because, in its absence, no valuable projects can ever be successfully pursued and ethical autonomy cannot be exercised except exclusively in the service of trivial decisions such as where to sleep and when to eat. ${ }^{81}$ Nor, of course, can one be autonomous in the absence of the ability for rational decision making. It follows that autonomy is dependent on bodily, mental and emotional health, bodily integrity and the ability to make rational choices. The cultivation of our mental abilities and practical reasoning depends heavily on a basic education not least because much depends, at least in modern societies, in terms of both autonomy and well-being, on our understanding of the options at our disposal. In fact, this is how autonomy and well-being come together in another interesting way: they both require, in different ways, opportunities for the individual to pursue. Of course, in terms of well-being, the satisfaction of basic needs is also significant on the grounds that it prevents pain, which, other things being equal, undermines well-being. But, as we saw, they are also important because they allow for the pursuit of various projects.

So, this is how I propose to go about a balancing capable of resolving the conflict between autonomy and well-being that runs through the notion of paternalism. On the one hand, we have free choice, which is intrinsically valuable: every restriction is regrettable and in need of special justification. On the other hand, the gain from a paternalistic interference that seeks to secure a threshold level of basic goods is threefold. Firstly, it promotes personal well-being, because the satisfaction of these goods is part of the good life. Secondly, it makes the pursuit of a vast number of diverse projects possible and these projects are the most integral part of self-authorship because they reflect our values and define the kind of life we lead. This process is closely related to the core of the ideal and practice of ethical autonomy,

\footnotetext{
${ }^{81}$ This is not to say that trivial options are insignificant for autonomy but rather that they are not enough to form an adequate range of options. This explains why the interference with trivial choices restricts autonomy.
} 
which is most meaningfully exercised when we make long term plans. Thirdly, it furnishes the autonomous person with an absolutely essential precondition for the exercise of free choice, since meaningful free choice is virtually impossible when our basic needs are not satisfied. If there ever is a good reason to sacrifice a small part of our freedom of choice, this threefold benefit must qualify. This brand of paternalism is a justifiable restriction of free choice (which lies at the core of personal autonomy) because it serves both personal well-being and selfauthorship. But it must satisfy two more criteria. It must, firstly, be efficient: the restriction is not justifiable unless it can, in practice, produce the positive outcome just described. Secondly, the restriction must be minor. By minor I mean limited in scope as well as mild (here mild refers to the means used for paternalistic purposes). This is necessary for two reasons, on which I will say more in the next section: a) paternalism should not, by definition, be punitive - people should not be led to believe that they are punished for their life choices; $b$ ) paternalistic measures should only affect the choices that can reduce basic goods to a nonacceptable level. So, paternalism is justified when it seeks, through minor and mild restrictions of autonomy, to protect a threshold level of those basic goods that are components of the good life and, at the same time, secure the conditions for both autonomy and the successful pursuit of projects; in all other cases, autonomy will, in principle, be the dominant value.

\subsection{Checkpoint: dealing with the two main objections}

The discussion so far has revolved around two central and yet competing notions that are inherent in paternalism: freedom and well-being. The anti-paternalist objection concerning the latter is that personal well-being cannot be promoted by autonomy-restricting means. Indeed, well-being has a strong subjective aspect: generally speaking, it makes no sense to 
claim that people can live well even if they do not believe that their lives are good. This entails that people should endorse their ways of life in order to live well. And, while autonomy is not indispensable to endorsement (because people can later endorse a non-autonomously chosen pursuit), it is a rather safe path to take (especially as far as state paternalism is concerned) if personal well-being is what we care about. However, we saw that these points are only partially true. The aspect of well-being that relies on the successful pursuit of projects and relationships cannot be promoted by paternalistic means. The aspect, however, that relies on the enjoyment of a threshold level of all-purpose goods can. So, in conclusion, the objection, in its unqualified form, is unfounded.

The objection from autonomy is a more complex one. As we saw, a lot depends on what one believes autonomy's value to be. If autonomy were only instrumentally valuable, as a contributor to well-being, the paternalistic point would be easier to make: well-being would, in principle, prevail. Autonomy, however, is also valuable qua autonomy and, therefore, its restriction requires special justification. The harm principle provides a rather uncontroversial one, since most of us regard the prevention of harm to others as a self-evident duty of every state. Harm to one's own well-being, on the other hand, cannot rely on such obvious considerations of justice. The admission that autonomy is not the only value worthy of protection is not particularly useful either. If a balancing of values is in order in the case of paternalism, we need to explain how this balancing is supposed to work. Nor can we simply say that autonomy can be restricted for the sake of autonomy. To be sure, autonomy is a matter of degree: people can have more or less of it. And there is no doubt that some autonomously made decisions can result in less autonomy for the future, by limiting, for example, the range of options available to the chooser. We must not forget, however, that 
autonomy is here understood as self-authorship, not merely as freedom from interference or positive freedom. And self-authorship is about making choices that may very well affect future decision-making. Studying provides a useful example: what we choose to study at age eighteen normally rules out a huge amount of options in several areas of life, with employment being the most obvious one. But no one would seriously propose paternalistic policies in this area of life. In fact, this argument could justify almost any kind of paternalistic intervention, if not properly qualified. In addition, as it stands, it can provide no guidance for public policy and legislation. It is too vague, indiscriminate and prone to the kind of abuse against which the liberal anti-paternalists have issued numerous warnings. We need more on the scale to outweigh the intrinsic value of free decision-making and this is what this analysis attempted to show. When paternalism protects the basic conditions for self-authorship as well as those goods whose enjoyment, at a threshold level, is both essential for well-being and attainable by non-autonomous means, autonomy justifiably makes way. It remains a central value to the society that adopts this rule, though not one that is lexically prior to all others. As far as autonomy is concerned, the argument is not that 'autonomy can be restricted now for the sake of more autonomy later'. Autonomy requires free choice but its ultimate purpose and most important moral aspect is self-authorship. By restricting free choice, the brand of paternalism I am defending here does not seek to provide more choice for later but to prevent the deterioration of certain basic goods to a level which jeopardises selfauthorship itself. Autonomy is, as we saw, not merely an ideal but an exercise concept as well. Therefore, the capacity to exercise self-authorship must be protected, even at the expense of free choice, provided that the other conditions described above are met. In a sense, the resulting paternalistic measures are in the spirit of the Millian ban on slavery contracts: they minimise the risk of utterly forfeiting self-authorship. 


\subsection{The objections from ethical autonomy}

\subsubsection{Paternalism vs. dignity and self-respect}

Choosing for ourselves and accepting responsibility for our choices is, as we saw, valuable for its own sake. When something is valuable in this sense, it can still give way to another value - provided, of course, that, on balance, this is what ought to be done. However, this brand of ethical autonomy, as I called it, has another important aspect: since the value of autonomous choice is closely related to reasoning as a unique human capability, there seems to be something wrong when people are forced to make choices that are not fully theirs. What seems to be implied here is that the paternalist is the superior decision -maker who legislates for his less than capable subject. ${ }^{82}$ What may be lurking in the shadows is the concession that the paternalistic relation is one of superior to inferior. ${ }^{83}$ So, the preceding analysis may have led us into a different kind of trap: by restricting people's ethical autonomy for their own good we can be accused of insufficient respect for their equal status and dignity.

Doug Husak attempts to explain why this attitude of domination, as I will call it for lack of better term, is not a necessary element of paternalism by pointing to instances of selfpaternalism, in which we seek to safeguard our interests against our own bad judgment by inviting someone else to restrain us in one way or another. ${ }^{84}$ To illustrate the point he reminds us of Odysseus who famously asked his men to tie him to the mast and not release him no matter how strongly he pleaded. ${ }^{85}$ Surely, if such self-paternalism is conceivable it cannot be said that all paternalism involves domination. This argument explains much of what happens

\footnotetext{
82 F. H. Buckley, Fair Governance, (Oxford: Oxford University Press, 2009), 19.

${ }^{83}$ Arthur White, Paternalism, (PhD dissertation, University of Virginia, 1974) as quoted in Douglas Husak, 'Paternalism and Autonomy', (1981), Vol. 10 (1), Philosophy and Public Affairs , 41.

${ }^{84}$ Husak, n 83, 43.

$85 \mathrm{lbid}, 44$
} 
in certain cases of private paternalism (including some not involving self-paternalism - a friend who does not stop the car so that we can buy a hamburger or cigarettes is a good example ${ }^{86}$ ) but it seems to be of limited force as regards legal paternalism, since it all seems to depend on a kind of communication that is not possible between the legislator and the citizens. Generally speaking, the law cannot know that I wish to restrict myself nor the special circumstances that may call for an all-in-all welcome interference with a passing impulse, like the craving for unhealthy food.

But the Homeric example can, properly modified, explain why paternalism -rather than self-paternalism in particular- is not necessarily an expression of domination. Remember that Odysseus decided to ask his men to bind him instead of simply sealing his ears like the rest aboard the ship, because he desired to hear the sirens' legendary singing. He knew, however, that succumbing to their love call is a human weakness he could not overcome. So, even if, in an alternative scenario, his men jumped up from their seats and restrained him without having been asked to do so in advance, there would be no disrespect or domination in their conduct. It is not that Odysseus exhibits a weakness that makes him look inferior in his comrades' eyes (let alone incapable of managing his own affairs) but rather that he is 'only human': how can he be expected to resist the sirens' song?

More modestly, we can point out that the brand of paternalism defended here simply seeks to address human fallibility which is, by nature, something common for all persons. This is not to say that human beings cannot know everything - this, no doubt, is not overlooked by the anti-paternalists who insist, following in the steps of Mill, that we are far more likely to make good decisions for ourselves than any government ever is. It is rather a reminder of

\footnotetext{
${ }^{86} \mathrm{Ibid}, 45$.
} 
the -by now equally obvious- fact that we tend to make predictable errors when deciding for ourselves. Thaler and Sunstein illustrate the point by making the distinction between Econs and Humans: Econs always choose rationally and never fail to serve their causes. But they are imaginary: they only exist in Economics textbooks; Humans, on the other hand, are (more or less) fallible - they are real people who are often misinformed, biased, lazy decision-makers and so on. ${ }^{87}$ We are in position to know that people often attach too much value to shortterm benefits and too little value to long-term ones; ${ }^{88}$ that every time we find out of a horrific accident, we tend to overestimate the probability of the same thing happening to us; ${ }^{89}$ that we can be fearful of change, even when change is clearly profitable and so on. A paternalistic interference motivated by the need to protect people from the most harmful among such known instances of bad decision-making does not (necessarily) constitute 'looking down on people'. Furthermore, this is even more the case with legal paternalism, since the law, in its generality, can avoid addressing specific individuals or groups. So, a ban on drug use is not meant to address current drug users in particular and it is this feature that makes this point even more relevant to legal paternalism.

Interestingly, the libertarian paternalism (LP) defended by Thaler and Sunstein (and those who followed after them) is much more useful in showing why paternalism does not depend on the view that some people are inferior and need guidance rather than in addressing the conflict of intuitions described in the introduction. Remember LP's promise: it professes to be able to lead people to decisions that are good for them without violating their

\footnotetext{
${ }^{87}$ Thaler and Sunstein, n. 65, 6-7 and $17 \mathrm{ff}$.

${ }^{88}$ This is what behaviourists call 'hyperbolic discounting'. For a similar point regarding paternalism, see Anthony Ogus, 'The Paradoxes of Legal Paternalism and How to Resolve Them', (2010), 30 Legal Studies, 66. ${ }^{89}$ For a detailed analysis of this point see T. Kuran and C. R. Sustein, 'Availability Cascades and Risk Regulation', (1999), 51 Stanford Law Review, 683.
} 
freedom. According to the definition adopted here, non-autonomy violating policies of this kind would not constitute paternalism in the first place. In fact, there would be nothing controversial with these state policies, provided that we are not moral relativists (Thaler and Sunstein insist that they want to help us do what we already want to do but, as many critics have shown, they too rely on an objective understanding of well-being). In any case, I can now state what I merely implied earlier: LP does restrict personal autonomy. It takes advantage of our knowledge of how people end up making bad decisions and turns this knowledge against bad decision-making. But the individuals who benefit are not decision-makers any more, at least not in any substantial sense that can be accommodated within the concept of autonomy as self-authorship. They enter a cafeteria with the intention of eating a burger and end up with a salad, due to LP's smart 'choice architecture' (again, assuming that it always works). The decision-making process is usurped and the options are magically hidden away on the top shelf, to remember the candy jar example. But is this not what traditional paternalism does? Interestingly, the answer is no. LP bypasses the decision-making process in a way that leaves the paternalised unaware of how or why she ended up with a healthy meal or a good pension or being an organ donor. So, it fails to respect her as a rational autonomous agent because it does not even address her as one (maybe it is not an intuitively appealing idea but, in fact, coercion relies on the assumption that we can make the rational choice and, for example, give up our money instead of our life).${ }^{90}$ But there is another crucial way in which LP fails to satisfy the requirements of the preceding analysis: a liberal paternalist ought to seek, before anything else, to educate. This is particularly true in the case of legal paternalism, given the

\footnotetext{
${ }^{90}$ Some theorists believe that choice architecture is manipulative - see, for example, Conly, $\mathrm{n} 48,30$. In some cases, where the way options are presented to the decision-maker can determine the decision, this makes sense. However, LP often makes no presentation at all and leaves effectively no room for decision-making. The discussion is too complex to advance here. Let me merely say that LP can usurp our decision-making in several ways, including manipulative ones.
} 
law's strong communicative power. Ideally, a good paternalistic law will make people stop and think about the reasons behind the interference (and, hopefully, endorse them). This is why paternalism must be transparent: when it is not, as in the case of LP, it hinders learning, which is essential for not repeating the same mistakes. ${ }^{91}$ Learning from our mistakes is, in turn, essential for taking our lives in our hands and exercising meaningful self-authorship. For these reasons, the liberal paternalism I am defending here is preferable to LP despite the fact that it allows for coercive measures, much like 'traditional' paternalism does. However, even if behavioural economics cannot help us lead people to good choices by autonomy-respecting means, they contribute to the paternalistic project in two important ways: firstly, they tell us that all people -rather than some who are not smart or educated enough- make mistakes and, therefore, there is no domination on the part of policy-makers who merely attempt to address human fallibility; secondly, they tell us how and why people make mistakes, thus helping the policy-makers adopt efficient paternalistic measures.

\subsubsection{Paternalism vs. lifestyles and ethical independence}

In my discussion of ethical autonomy I emphasised the value of making our own decisions, especially when these are life-shaping decisions. I made it clear that at the core of the notion lies the most integral and valuable part of self-authorship because it is the choices we made regarding long term plans and pursuits (including relationships) that tell the story of our lives more than anything else. Then I explained that the brand of liberal paternalism defended here has no business interfering with this part of ethical autonomy, i.e. with people's life-shaping projects. I backed up this view by asserting that any kind of paternalism that would target

\footnotetext{
${ }^{91}$ See Till Grüne-Yanoff , 'Old wine in new casks: libertarian paternalism still violates liberal principles', (2012) Social Choice and Welfare 38 (4), 637.
} 
these choices would be impossible to defend because it is a major restriction of personal autonomy that cannot bear fruit in terms of well-being. Forcing people to adopt valuable plans and pursuits is ineffective because these aspects of well-being require genuine endorsement: no life is good from the point of view of the person whose life it is unless that person is genuinely committed to her pursuits. A misanthrope will not live a better life if he enjoys the love and affection of others unless he gets to endorse these loving relationships as serving his well-being. ${ }^{92}$

So far so good but, as I have already mentioned in passing, endorsement does not necessarily require free choice. It is perfectly conceivable that people may be forced today to adopt a plan that they will wholeheartedly endorse later. Is this not what we casually do with (or to) children? How many famous musicians and scientists freely chose to study their (now) favourite instrument or subject? Very few, no doubt. With time, they came to love and endorse a pursuit that made their lives fulfilling and successful both objectively and, more importantly, from their point of view. Perhaps the state could follow the same path by allowing for a 'trial period' before removing the paternalistic imposition when all reasonable hope for endorsement is lost. ${ }^{93}$ But even if we concede that these policies would, with certain rigid limitations in place, be compatible with the ethical autonomy of adults, they would be impossible to implement. This kind of paternalistic approach is only possible in the context of close personal relations. Even if there is a way to know which projects each particular citizen would be most likely to endorse in the future, there is no way for the state or the legislator to know what constitutes a trial period in each individual case. Paternalistic policies of this kind would necessarily have to rely on general statistics or simplified assumptions that would,

\footnotetext{
92 Ronald Dworkin, n 29, 217.

${ }^{93}$ Ronald Dworkin, n 29, 269.
} 
inevitably, seriously damage both self-authorship and personal well-being in a great number of cases. For the liberal paternalist, the free choice of projects, pursuits and relationships is the only available course of action.

There is one final point to be made regarding ethical autonomy and the protection of comprehensive plans and pursuits from paternalistic interference. In one of his discussions of dignity, Ronald Dworkin argued for ethical independence as part of authenticity, which itself is one of the two principles of dignity (the other being self-respect ${ }^{94}$ ). A violation of ethical independence denies people the power to make their own decisions about the character of their lives, a power that is of paramount importance for self-respect. ${ }^{95}$ It is of equal importance to self-authorship, because these decisions (about long-term plans, comprehensive goals etc) define our lives much more than any trivial choice ever will. In addition, we saw how a consistent failure to commit to the things we value about our life cannot be what we really want in terms of self-authorship. Generally speaking, the people who protest against seatbelt laws do not want to risk their pursuits and relationships merely to avoid a minor inconvenience. They either miscalculate the dangers involved (and we can know this with some certainty thanks to the behavioural sciences) or protest that the 'nanny state' is treating them as children or seeks to take their freedom away from them. As we saw, neither accusation is (more precisely: needs to be) true. The brand of liberal paternalism I am defending here is not hostile to ethical independence. On the contrary, by securing the essential requirements for self-authorship, it secures ethical independence. The legal requirement to wear protective gear on a construction site can ensure the ability of those

\footnotetext{
94 Ronald Dworkin, Justice for Hedgehogs, (Cambridge, Mass: Harvard University Press, 2011), $202 \mathrm{f.}$

${ }^{95}$ Ronald Dworkin, n 29, 368.
} 
who engage in construction work to advance their careers and life pursuits without passing judgment on their content and character.

Of course, there are always those who do not wish to live autonomously, who regard autonomy as an evil. They may be few, but they are right to point out that two of the three weights we place on the scale (namely, the protection of the goods that are both a precondition for autonomous self-authorship and essential for adopting projects) do not apply to them. I think that the actual effects to their lives will be minimal, provided that paternalism remains mild. In any case, if autonomy is valuable qua autonomy, a state should not be apologetic for protecting it by moderate and well thought-out means. And, of course, there is always the occasional Evel Knievel, ${ }^{96}$ for whom risk is a life project - in fact, his main project. Again, notwithstanding the fact that these lifestyles are rare exceptions, I think that appropriately mild paternalistic laws can accommodate them: if all Evel has to do is take some safety measures and pay a fine when he fails to do so, he will continue to author his life with little injury (with the exception of broken bones). Even Evel did not really want to hurt himself and, as long as he is not coerced out of his lifestyle, he cannot blame the legislator for looking down on him or preventing him from authoring his own life. Obviously, I am assuming that Evel's life would be pointless, from his point of view, unless he were allowed to perform his stunts. If he could simply take up gardening instead, his claim to be left alone by paternalism would not be as pressing. Needless to say, that there are many valuable activities that include risk of injury and even death. The liberal paternalistic interference defended here should seek to reduce the risk by mild means. Seatbelt laws provide a good example of this kind of interference.

\footnotetext{
${ }^{96}$ Evel was a famous stuntman and daredevil.
} 


\section{In conclusion}

The preceding remarks help us to appreciate welfare paternalism not as an exception to a general 'pro-freedom' rule or a 'necessary evil' but rather as a principle in the service of wellbeing and autonomy. They provide a solid justification for paternalistic legislation regarding drugs that pose serious health risks and impair rational decision-making. They point to the need for laws that make various safety measures mandatory, including seatbelts, motorcycle helmets and other types of protective gear. They allow for health insurance and pension schemes to become mandatory as well. Parents may be legally required to provide their children with a basic education even if this is against their (the parents') beliefs - this would be a typical case of indirect paternalism. Extremely dangerous activities, like sailing in a storm or swimming in shark-infested waters may be banned and law enforcement agencies may be given the authority to physically remove those who do not comply. Dangerous products may be removed from the market, even if there are people who wish to buy or consume them. There is, however, a point we must keep in mind: paternalism, even coercive legal paternalism, is not a form of punishment. Therefore, it must seek, just like a parent, to help, support and educate the paternalised and respect her as a rational autonomous agent. ${ }^{97}$ It follows that paternalistic laws must be mild so that they do not give the impression of punishment but of parental protection. Imprisonment is, in principle, out of the question, since paternalism aims at the promotion of autonomy and well-being, not their deterioration. Respect for the ethical aspect of autonomy and people's autonomously chosen life-shaping pursuits also requires that when the imposition of safety measures is possible, these should be preferred over a complete ban of the activity in question.

\footnotetext{
97 John Finnis, Natural Law and Natural Rights (Oxford: Clarendon Press, 1980), 220.
} 


\section{Bibliography}

Arneson Richard, 'Mill versus Paternalism', (1980), Vol. 90 (4), Ethics, 470-489

Arneson Richard, 'Autonomy and preference formation', in In Harm's way, Essays in Honor of Joel Feinberg, ed. Jules Coleman and Allen Buchanan (Cambridge University Press, 1994), 4275

Arneson Richard, 'Perfectionism and Politics', (2000), Vol. 111, (1), Ethics, 37-63

Benn Stanley, A Theory of Freedom, (Cambridge: Cambridge University Press, 1988),

Berlin Isaiah, introduction to Five Essays on Liberty, ed. Henry Hardy (Oxford: Oxford University Press, 2002)

Berlin Isaiah, 'Two concepts of liberty' in ed. A. Quinton, Political Philosophy, (Oxford: Oxford University Press, 1967)

Bratman Michael, Intention, Plans and Practical Reason, (Center for the Study of Language and Information, 1999),

Buckley F. H., Fair Governance, (Oxford: Oxford University Press, 2009) 
Christman John, 'Constructing the Inner Citadel: Recent Work on the Concept of Autonomy', 99 Ethics, (1988), 109-24.

Conly Sarah, Against Autonomy: Justifying Coercive Paternalism, (Cambridge: Cambridge University Press, 2013)

Crisp Roger, 'Raz on Well-Being', (1997), Vol.17, (3) Oxford Journal of Legal Studies 499-515

Dworkin Gerald, 'Paternalism' in eds. P. Laslett and J. Fishkin, Philosophy, politics and society, (Oxford: Blackwell, 1979)

Dworkin Gerald, 'Paternalism: Some Second Thoughts', in ed. Rolf Sartorius, Paternalism, (Minneapolis: University of Minnesota Press, 1983), 105-111

Dworkin Gerald, 'Review: The Morality of Freedom', (1988), Ethics, Vol. 98, No. 4, 850-852

Dworkin Gerald, 'The Concept of Autonomy' in The Theory and Practice of Autonomy, (Cambridge: Cambridge University Press, 1988)

Dworkin Ronald, Is Democracy Possible Here?: Principles for a New Political Debate, (Princeton University Press, 2006)

Dworkin Ronald, 'Sovereign Virtue: The Theory and Practice of Equality, (Harvard University Press, 2000)

Dworkin Ronald, Justice for Hedgehogs, (Cambridge, Mass: Harvard University Press, 2011)

Ekstrom Laura Waddell, 'Autonomy, Alienation and the Self' in P. French and H. Wettstein eds. Free Will and Moral Responsibility, (Boston MA and Oxford UK: Blackwell Publishing, 2005) 
Feinberg Joel, The Moral Limits of the Criminal Law Volume 3: Harm to Self, (New York:

Oxford University Press, 1989)

Feinberg Joel, 'Autonomy' in The Inner Citadel: Essays on Individual Autonomy ed. John Christman (Oxford University Press, 1989), 35-6.

Finnis John, Natural Law and Natural Rights (Oxford: Clarendon Press, 1980)

Finnis John, 'The Legal Enforcement of Duties to Oneself: Kant v. Neo-Kantians', (1987), Vol.

87 Columbia Law Review, 433-456

Frankfurt Harry, 'Freedom of the Will and the Concept of a Person', (1971), Vol. 68, (1) The Journal of Philosophy, 5-20

Galston William, 'Two concepts of liberalism', (1995), Vol. 105, (3) Ethics, 516-534

Gardner John, 'Prohibiting Immoralities', (2007), Vol. 28 (6), Cardozo Law Review, 26132629

George Robert, 'The Unorthodox Liberalism of Joseph Raz', (1991), Vol. 53 (4), The Review of Politics, 652-671

Grüne-Yanoff , Till ‘Old wine in new casks: libertarian paternalism still violates liberal principles', (2012) Social Choice and Welfare 38 (4), 635-645.

Hobhouse L T, Liberalism, (Oxford: Oxford University Press, 1981)

Hurka Thomas, Perfectionism, (Oxford: Oxford University Press, 1993)

Husak Douglas, 'Paternalism and Autonomy', (1981), Philosophy and Public Affairs Vol. 10 (1), 27-46. 
Kleinig John, Paternalism, (New Jersey: Rowman and Allanhead, 1983)

Kukathas Chandran, The Liberal Archipelago: A Theory of Diversity and Freedom, (Oxford:

Oxford University Press, 2003)

Kuran T, and Sustein C R, 'Availability Cascades and Risk Regulation', (1999), Vol. 51 (4)

Stanford Law Review, 683-768

Kymlicka Will, Liberalism, Community and Culture, (Oxford: Clarendon Press, 1991)

Lamond Grant, 'The Coerciveness of Law', (2000), Vol. 20, (1) Oxford Journal of Legal Studies, 39-62

Mill J. S., On Liberty and Other Essays, (Digireads.com Publishing, 2010)

Nozick Robert, Anarchy, State and Utopia, (Oxford: Blackwell, 1974)

Nussbaum Martha, Women and Human Development: A Study in Human Capabilities, (Cambridge: Cambridge University Press, 2000)

Nussbaum Martha, Creating Capabilities: The Human Development Approach, (Cambridge, Mass. and London: Harvard University Press, 2011)

Ogus Anthony, 'The Paradoxes of Legal Paternalism and How to Resolve Them', (2010), 30 Legal Studies, 61-73

Rawls John, $A$ Theory of Justice, (Cambridge, Mass: Harvard University Press, 1971)

Raz Joseph, The Morality of Freedom, (Oxford: Clarendon Press, 1986)

Raz Joseph, 'Facing Up', 62 Southern California Law Review, (1989), 1153-1215 
Raz Joseph, 'The Role of Well-Being' (2004), Vol. 18, Philosophical Perspectives, 269-294

Regan Donald, 'Authority and Value: Reflections on Raz's The Morality of Freedom', (1989), Vol. 62 Southern California Law Review, 995-1085

Sadurski Wojciech, 'Joseph Raz on Liberal Neutrality and the Harm Principle', (1990), Vol. 10 Oxford Journal of Legal Studies, 122-133

Scanlon Thomas E., 'Reasons and Passions' in Sarah Buss \& Lee Overton (eds.), Contours of Agency: Essays for Harry Frankfurt, (MIT Press, 2002)

Sher George, Beyond Neutrality: Perfectionism and Politics, (Cambridge University Press, 1997)

Stanton-Ife John, 'The Limits of Law' in the Stanford Encyclopedia of Philosophy, (2006) Section 4, <http://plato.stanford.edu/entries/law-limits/>

Strawson Galen, Freedom and Belief, (Oxford: Clarendon Press, 1986)

Taylor Charles, 'What is Human Agency?' in Philosophical Papers (Cambridge: Cambridge University Press, 1985)

Thaler Richard E. and Sunstein Cass R., Nudge: Improving Decisions about Health, Wealth, and Happiness, (New Haven and London: Yale University Press, 2008)

Van Parijs Philippe, Real Freedom for All: What (If Anything) Can Justify Capitalism?, (Oxford: Oxford University Press, 1995)

Waldron Jeremy, 'Autonomy and Perfectionism in Raz's Morality of Freedom', (1989), 62 S. Cal. L. Rev. 1097-1152 
Wall Steven, Liberalism, Perfectionism and Restraint, (Cambridge: Cambridge University Press, 1998)

Watson Gary, 'Free Agency', (1975) The Journal of Philosophy, Vol. 72 No. 8, 205-220

White Arthur, Paternalism, (PhD dissertation, University of Virginia, 1974)

Williams Bernard, 'From Freedom to Liberty: The Construction of a Political Value', (2001), Vol. 30 (1) Philosophy and Public Affairs, 3-26

Young Robert, Personal autonomy: beyond negative and positive liberty, (Saint Martin's Press Inc., 1986) 